\title{
SUNSCREEN ACTIVITY OF SUGAR PALM (Arenga pinnata (Wurmb.) Merr.) LEAF STALK ASHES EXTRACT
}

\author{
${ }^{1}$ Esti Rachmawati Sadiyah, ${ }^{1}$ Endah Rismawati Eka Sakti and ${ }^{1}$ Indah Ratnasari \\ ${ }^{1}$ Department of Pharmacy, Faculty of Mathematics and Natural Sciences, Universitas Islam Bandung, Bandung, \\ Indonesia \\ Corresponding author: esti_sadiyah@ymail.com
}

\begin{abstract}
Sugar palm leaf stalk (petioles) ashes traditionally used as a daily cosmetic by Sundanese women to keep their skin smooth. Sugar palm leaf stalk ashes also used to treat acne, smallpox, and burns. The study was aimed to test the sunscreen activity of ashes extracts from sugar palm leaf stalk. The ashes were extracted using soxhlet and $96 \%$ ethanol as solvent. The sunscreen activity test was performed on the extract using UV-Vis spectrophotometer. Determination of Sun Protection Factor (SPF) value was done at 290-320 nm (UV-B wavelength) with $5 \mathrm{~nm}$ interval. The ashes extract of sugar palm leaf stalk showed the effectiveness of sunscreen activity at $10,000 \mathrm{ppm}$ (SPF value $=9$ ) as maximum protection. The SPF value was determined using Mansur mathematical equation. The determination of pigmentation transmittant was done at $322.5-372.5 \mathrm{~nm}$, with $2.5 \mathrm{~nm}$ interval. Based on the result of pigmentation transmittance percentages, the sunscreen profile of sugar palm leaf stalk ashes extract (2000-10.000 ppm) showed the category of extra protection up to sunblock, according to classification from Balsam \& Sagarin (1972). To be concluded, the ashes extract of sugar palm leaf stalk was a potential sunscreen. Further in vivo analysis should be done to confirm this potency.
\end{abstract}

Keywords: ashes, sugar palm, sunscreen, pigmentation.

\section{INTRODUCTION}

Sugar palm (Arenga pinnata (Wurmb.)

Merr.) grows naturally in South East Asia to

East Papua, and in Indonesia known as “aren”, "enau” or "kawung” (Smits, 1996 :

53). The leaves of sugar palm are pinnates

and its leaf stalk (petioles) have sheath at the base (Smits, 1996: 55). All parts of sugar palm from the root, stem, leaves, inflorescence and fruit are useful. The main product is "nira", or the sweet and aromatic fresh juice collected from tapping the stalk of inflorescence. Fermentation of the juice can be made into vinegar and brown sugar. Stem extraction can produce starch, and the white endosperm of immature seed are boiled with sugar to produce sweetmeat ("kolangkaling”). Long black-grey fibres (“ijuk") can be collected from the trunk, the roots, the pith of the trunk, and leaf stalks (Smits, 1996: 54). 
"Sarerang kawung" is the ashes resulted from the leaf stalk of sugar palm which is used for traditional cosmetics ingredient. Sundanese women in the past used sarerang kawung for facial powder to keep their skin smooth (Suwartapradja, 2003: 4). Sarerang kawung also used to treat acne, smallpox, and burns (Hidayati, 2009).

Lestari (2013: 3-4) had done the tyrosinase inhibition activity test of sugar palm leaf stalk ashes water extract and resulted $\mathrm{IC}_{50}$ value of $1,458.98 \mu \mathrm{g} / \mathrm{mL}$, while the value resulted from ethanol extract was 1,960.91 $\mu \mathrm{g} / \mathrm{mL}$. The ashes contained five minerals that may have a role in tyrosinase inhibition, such as $\mathrm{Al}(344.56 \mathrm{mg} / \mathrm{kg}), \mathrm{Mg}$ $(82.6 \mathrm{mg} / \mathrm{kg}), \mathrm{Fe}(26.76 \mathrm{mg} / \mathrm{kg}), \mathrm{Zn}(6.10$ $\mathrm{mg} / \mathrm{kg}$ ), and $\mathrm{Cu}(3.77 \mathrm{mg} / \mathrm{kg}$ ) (Lestari, 2013: $5)$.

$\mathrm{Zn}$ contained in sugar palm leaf stalk ashes was one of inorganic substances that can be used as physical sunscreen. Physical blocker or particulate sunblock or inorganic sunscreen is the kind of powder that reflects or distorts ultra violet (UV) radiation. Physical sunscreen contain inert mineral particles such as titanium dioxide (TiO2), zinc oxide ( $\mathrm{ZnO})$, talk (silicate magnesium), magnesium oxide, kaolin, fero or ferioxide, barium sulfic, silicate, mica, and red petrolatum (Benson, et al., 2008 in Subchan, et al.,2011:145).

According to these information, sugar palm leaf stalk ashes contained the inorganic substances that can be used as physical blocker, but there was no explanation about the sample's sunscreen activities concerning Sun Protection Factor (SPF) values or percentages of Erythema and Pigmentation Transmittance (\% Te and \% Tp). For this reason, the research was conducted to test the sunscreen activity of sarerang kawung based on SPF, \%Te and \%Tp.

\section{RESEARCH METHODS}

Sugar palm leaf stalk was collected from Cisewu village, Garut, West Java. Plant species determination was done in Herbarium Jatinangor, Laboratory of Plant Taxonomy, Department of Biology, Mathematics and Natural Sciences, Universitas Padjajaran.

The leaf stalk that were used were the ones that already old, solid, dry, with brownish-yellow to brown colored sheath. 
The leaf stalk were cut into pieces with 25-30 cm length, and burned for 1-2 hours to produce the greyish-white ashes. After the fire goes off, the ashes were left to cold for one night.

Sugar palm leaf stalk ashes were extracted using soxhlet and $96 \%$ ethanol as solvent with 1:8 ratios. The extract collected was then concentrated using waterbath in $50^{\circ} \mathrm{C}$.

Sunscreen activity test was done in vitro by determination of Sun Protecting Factor (SPF) value, erythema and pigmentation transmittance percentages using UV-Vis Spectrophotometry. The extract was tested on 2,000;4,000;6,000;8,000 and $10,000 \mathrm{ppm}$ and ethanol was used as blank sample. The absorbance measured showed the substance's activity in absorbing or reflecting UV light in the sample. For SPF value determination, absorbance was measured in UV-B radiation wavelength (290-320 nm) with $5 \mathrm{~nm}$ interval. Triple measurement was done for each wavelength.
SPF value calculated from the absorbance measured, based on Mansur mathematical equation (Donglikar \& Deore, 2016: 172):

SPF spectrophotometric $=$ $C F \times \sum_{290}^{320} \operatorname{EE}(\lambda) \times \mathrm{I}(\lambda) \times \operatorname{Abs}(\lambda)$

With: EE (I)-erythemal effect spectrum; I (1)-solar intensity spectrum; Abs (1)-absorbance of sunscreen product; CFcorrection factor $(=10)$. The value of $\operatorname{EE}(\lambda) \mathrm{x}$ I $(\lambda)$ is constant and normalized as stated in Table 1 (Donglikar \& Deore, 2016: 172). Table 2 showed the categories of sunscreen based on the value of SPF (Schalka \& Reis, 2011: 514).

The percentages of erythema and pigmentation transmittance measurement were done on the samples using the same concentration as SPF measurement. Erythema transmittance was measured at 292.5-317.5 nm, and pigmentation transmittance at $322.5-372.5 \mathrm{~nm}$, with $2.5 \mathrm{~nm}$ interval. Triple measurement was done for each wavelength. 
Sunscreen Activity of Sugar Palm....

Table 1. Normalized product function in the calculation of SPF

\begin{tabular}{|c|c|}
\hline Wavelength $(\lambda)$ in $\mathrm{nm}$ & EE x I (normalized) \\
\hline 290 & 0.0150 \\
\hline 295 & 0.0817 \\
\hline 300 & 0.2874 \\
\hline 305 & 0.3278 \\
\hline 310 & 0.1864 \\
\hline 315 & 0.0839 \\
\hline \multirow[t]{2}{*}{320} & 0.0180 \\
\hline & Total l \\
\hline
\end{tabular}

Table 2. Categories of sunscreens based on the SPF value

\begin{tabular}{c}
\hline \hline Protection Level \\
\hline$\frac{\text { SPF Value }}{1 \text { Maximum }}$ \\
\hline $\begin{array}{c}\text { High } \\
\text { Medium }\end{array}$ \\
\hline Low \\
\hline \hline
\end{tabular}

The determination of sunscreen category was based on Balsam \& Sagarin (1972, in Athiyah et al., 2015: 183, Yasin, 2017: 17, and Whenny et al., 2015: 155) as stated in Table 5, using the formula as follow:

$$
\begin{aligned}
& \text { \% Te (Erythema Transmittance })= \\
& \frac{\Sigma \mathrm{Ee}}{\Sigma \mathrm{Fe}}=\frac{\Sigma(\mathrm{TxFe})}{\Sigma \mathrm{Fe}} \\
& \% \mathrm{Tp}(\text { Pigmentation Transmittance })= \\
& \frac{\Sigma \mathrm{Ep}}{\Sigma \mathrm{Fp}}=\frac{\Sigma(\mathrm{TxFp})}{\Sigma \mathrm{Fp}}
\end{aligned}
$$

With: Ee-Ertyhema energy, Ep-Pigmentation energy, T-Transmission, Fe-Erythema Flux, and Fp-Pigmentation Flux. The value of Erythema Flux for each wavelength is showed in Table 3, and Pigmentation Flux is showed in Table 4.

\begin{tabular}{|c|c|}
\hline Wavelength (nm) & Pigmentation Flux (Fp) \\
\hline $320-325$ & 0.1079 \\
\hline $325-330$ & 0.102 \\
\hline $330-335$ & 0.0936 \\
\hline $335-340$ & 0.0798 \\
\hline $340-345$ & 0.0669 \\
\hline $345-350$ & 0.057 \\
\hline $350-355$ & 0.0448 \\
\hline $355-360$ & 0.0456 \\
\hline $360-365$ & 0.0356 \\
\hline $365-370$ & 0.031 \\
\hline $370-375$ & 0.026 \\
\hline
\end{tabular}

Table 3. Erythema Flux

\begin{tabular}{c}
\hline \hline Wavelength (nm) \\
\hline \hline $\mathbf{2 9 0 - 2 9 5}$ \\
\hline $\mathbf{2 9 5 - 3 0 0}$ \\
\hline $\mathbf{3 0 0 - 3 0 5}$ \\
\hline $\mathbf{3 0 5 - 3 1 0}$ \\
\hline $\mathbf{3 1 0 - 3 1 5}$ \\
\hline $\mathbf{3 1 5 - 3 2 0}$ \\
\hline
\end{tabular}

Table 4. Pigmentation Flux

\section{RESULT AND DISCUSSION}

The sugar palm leaf stalk burning process yielded $0.95 \%$ of greyish-white ashes, while the extract was yellowish-white. Based on previous work by Ratnasari et al. 
(2018), the same sample of sugar palm leaf stalk ashes contained $\mathrm{Zn}(1,132.0567 \mathrm{mg} / \mathrm{kg}$ ashes), which was one of inorganic substances that can be used as physical sunscreen. The sample also contained manganese (Mn) $548.5737 \mathrm{mg} / \mathrm{kg}$, and selenium (Se) $109.4405 \mathrm{mg} / \mathrm{kg}$.

Table 5. Sunscreen Activity Categories

\begin{tabular}{|c|c|c|}
\hline \multirow{2}{*}{ Category } & \multicolumn{2}{|c|}{ Transmittance } \\
\hline & Erythema & Pigmentation \\
\hline Sunblock & $<1 \%$ & $3-40 \%$ \\
\hline Extra protection & $1-6 \%$ & $42-86 \%$ \\
\hline Standard suntan & $6-12 \%$ & $45-86 \%$ \\
\hline Fast tanning & $10-18 \%$ & $45-86 \%$ \\
\hline
\end{tabular}

In SPF value determination, sample absorbance were measured in UV-B radiation wavelength (290-320 nm). UV-B radiation is the main cause of sunburn (erythema) and also in charge for photo aging and photo carcinogenesis (Larsen, 1994 in Rai and Srinivas, 2007).

SPF value is accepted globally to estimate a sunscreen protection, especially for UV-B radiation (More, 2007). Based on the result showed in Table 6, the sample SPF value increased in higher concentration and the highest was $9.005 \quad(10,000 \mathrm{ppm})$. Although, according to sunscreen categories described by Schalka \& Reis (2011: 514), the value showed low protection level.

Table 6. The sample SPF Value and Protection Level

\begin{tabular}{|c|c|c|}
\hline $\begin{array}{c}\text { Concentration } \\
\text { (ppm) }\end{array}$ & SPF Value & $\begin{array}{c}\text { Protection } \\
\text { Level }\end{array}$ \\
\hline 2 & 2377 & Low \\
\hline 4 & 4284 & Low \\
\hline$\overline{6}$ & 6234 & Low \\
\hline$\overline{8}$ & 7333 & Low \\
\hline 10 & 9005 & Low \\
\hline
\end{tabular}

Beside of SPF value, the percentages of erythema and pigmentation transmittance may also describe the sample sunscreen protection level. According to Cumpelik (1972, in Yasin, 2017: 20), the percentages of erythema or pigmentation transmission are the accumulation of UV energy that is transmitted by sunscreen on erythema or pigmentation spectrum, compared to erythema efficiency factor in each wave length between 292.5-372.5 nm.

Table 7 showed that based on percentages of erythema transmittance, the sample with concentration 8,000 and 10,000 ppm had fast tanning sunscreen category. On the other hand, based on percentages of 
pigmentation transmittance, the same compared to the other sunscreen categories concentration showed sunblock activity.

(Athiyah et al., 2015: 186).

Athiyah et al. (2015: 184) mentioned

Fast tanning activity also showed by that a chemical substance has sunblock activity when it can totally protect the skin the sample with concentration 2,000 and 4,000 ppm, based on the percentages of from sunrays that may cause erythema and pigmentation, specifically UV-A (322.5$372.5 \mathrm{~nm})$ and UV-B (292.5-337.5 nm). On the contrary, substance with fast tanning activity absorb the least of UV-A and UV-B pigmentation transmittance, but the resulted percentages of erythema transmittance did not showed any sunscreen activities. This result appeared to describe the sample potency in skin protection from pigmentation, but may not prevent erythema.

Table 7 The sample percentages of erythema, pigmentation transmittances and sunscreen category

\begin{tabular}{|c|c|c|c|c|}
\hline $\begin{array}{c}\text { Concentration } \\
(\mathrm{ppm})\end{array}$ & $\% \mathrm{Te}$ & $\begin{array}{c}\text { Sunscreen } \\
\text { Category }\end{array}$ & $\%$ Tp & $\begin{array}{c}\text { Sunscreen } \\
\text { Category }\end{array}$ \\
\hline$\overline{2}$ & 259,372 & - & 74,660 & Fast tanning \\
\hline 4 & 46,860 & - & 58,771 & Fast tanning \\
\hline 6 & 28,706 & - & 41,743 & $\begin{array}{c}\text { Extra } \\
\text { protection }\end{array}$ \\
\hline 8 & 18,196 & Fast tanning & 30,182 & Sunblock \\
\hline 10 & 14,592 & Fast tanning & 26,622 & Sunblock \\
\hline
\end{tabular}

Higher sample concentration (6,000 more UV light with 290-320 nm wave length ppm) showed better activity in skin pretection (Wilkinson \& Moore, 1982, in Athiyah et al., from pigmentation (extra protection category), 2015:185).

but also did not prevent erythema because the resulted percentage transmittance was not included in the activity range. Sunscreen with extra protection category may absorb $95 \%$ or

Based on the result of erythema and pigmentation transmittance percentages, the sample of sugar palm leaf stalk ashes extract might have more activity in protecting the skin 
from UV-A radiation that cause pigmentation. The inorganic particles that contained in the ashes such as zinc, selenium, and manganese might have a contribution to this activity.

Smijs \& Pavel (2011: 96, 99) mentioned that $\mathrm{ZnO}$ is more efficient in $\mathrm{UV}-\mathrm{A}$ absorption, compared to $\mathrm{TiO}_{2}$. Zinc oxide $(\mathrm{ZnO})$ and titanium dioxide $\left(\mathrm{TiO}_{2}\right)$ are frequently used inorganic physical sun blockers. Both particles have UV attenuation properties from UV absorption, reflection and scattering of UV radiation and visible light. Antoniou et al. (2011: 1112) explained that $\mathrm{ZnO}$ and $\mathrm{TiO}_{2}$ as physical sunscreens are very efficient, photostable, and offer protection extending into the UVA and visible ranges with almost negligible irritation and sensitization potential.

$\mathrm{ZnO}$ and $\mathrm{TiO} 2$ have opaque characteristic when applied to sunscreen formula, although the whitening effect of $\mathrm{ZnO}$ is lower than $\mathrm{TiO} 2$. The opaqueness of these sunscreen formulations results from the ability to reflect and scatter UV radiation and visible light (Smijs \& Pavel, 2011).
To overcome the whitening effect from the big sized particles, titanium dioxide and zinc oxide are now frequently processed as microfine or nanoparticles $\quad(10-50 \quad \mathrm{~nm}$ compared with 200-500 nm of the nonmicronized form). These nanoparticles reflect/scatter and absorb UV, and they are transparent on the skin, thus enhancing the cosmetic acceptability of the product. Microfine $\mathrm{TiO}_{2}$ has an absorption profile greater in the UVB but extends in the long UV-A. Microfine $\mathrm{ZnO}$ has a flat absorption profile that spans UV-B and UV-A (Antoniou et al., 2011).

In other hand, selenium is one of natural products have been reported to enhance levels of antioxidant enzymes. Alpha-tocopherol (vitamin E), phloretin, ferulic acid, flavangenol, lipoic acid, uric acid, and a variety of flavonoids derived from plants are also known to have this activity (Amaro-Ortiz et al., 2014: 6210). Although the activity of this element did not directly interact with UVrays, the content of selenium in the sample of sugar palm leaf stalk ashes might add a value to its potency as sunscreen. 
The content of manganese in sugar palm leaf stalk ashes might also contribute to increase UV-A radiation absorption of the sample. Manganese doping has been shown to increase the UV-A:UV-B absorption ratio of titania, reduce free radical generation rates by over $90 \%$, and provide free radical scavenging behavior (Wakefield et al., 2004).

UV-A radiation comprises $90-95 \%$ UVrays to reach the earth surface. $\mathrm{UV}-\mathrm{A}$ radiation can cause tanning because of its ability to penetrate the skin deeper into the mid-dermis. UV-A radiation also can cause DNA damage, induce photo-carcinogenesis, photoimmunosuppression, photodermatosis, and photoaging (Barnetson, 2003 in Subchan, dkk., 2011:).

\section{CONCLUSION}

The ashes extract of sugar palm (Arenga pinnata (Wurmb.) Merr.) leaf stalk showed the potency to be developed as sunscreen, especially for protecting the skin from UV-A radiation, based on $\mathrm{Zn}$ and $\mathrm{Mn}$ content. The ashes content of selenium may also increase the level of antioxidant enzymes and improve its sunscreen activity. Further in vivo analysis should be done to confirm this potency.

\section{Refferences}

Amaro-Ortiz A., Yan B., and D'Orazio JA., 2014. Ultraviolet Radiation, Aging and the Skin: Prevention of Damage by Topical cAMP Manipulation, Molecules, 19: 6202-6219.

Antoniou C., Kosmadaki MG., Stratigos AJ., Katsambas AD., 2011. Sunscreens what's important to know, J Eur Acad Dermatol Venereol., 22:1110-1118.

Athiyah M., Islamudin A., Rijai L., 2015. Aktivitas Tabir Surya Ekstrak Akar Bandotan (Ageratum Conyzoides L.) Jurnal Sains dan Kesehatan, 1(4). pISSN: 2303-0267, e-ISSN: 2407-6082.

Donglikar MM., and Deore S., 2016. Sunscreens: A review, Pharmagocnosy Journal, 8(3): 171-179.

Hidayati N., 2009. Manfaat Pohon Aren, http://www.niahidayati.net/manfaat-

pohon-aren.html\#more-6

Lestari MES., 2013. Potensi Abu dan Simplisia Pelepah Aren (Arenga pinnata.Merr) sebagai Inhibitor Tirosinase. Skripsi Departemen Biokimia, Fakultas Matematika dan Ilmu Pengetahuan Alam Institut Pertanian Bogor. Bogor. https://repository.ipb.ac.id/bitstream/han dle/123456789/67797/G13mes.pdf?sequ ence $=1 \&$ isAllowed $=\mathrm{y}$

More BD., 2007. Physical sunscreens: On the comeback trail, Indian $J$ Dermatol Venereol Leprol, 73:80-5. Available from:

http://www.ijdvl.com/text.asp?2007/73/ $\underline{2 / 80 / 31890}$

Rai and Srinivas, 2007. Photoprotection, Indian J Dermatol Venereol Leprol. 73: 73-9. Available from https://tspace.library.utoronto.ca/bitstrea $\underline{\mathrm{m} / 1807 / 47876 / 1 / \mathrm{dv} 07028 . p d f}$ 
Sadiyah ER., Sakti ERE., Ratnasari I., JIF Farmasyifa, 2(1): 62 - 72

Ratnasari I., Sakti ERE., dan Sadiyah ER., 2018. Uji Aktivitas Antioksidan Abu Pelepah Aren (Arenga pinnata (Wurmb) Merr.), http://karyailmiah.unisba.ac.id/index.php /farmasi/search/titles?searchPage $=21$

Schalka S. and dos Reis VM., 2011. Sun Protection Factor: Meaning and Controversies, An. Bras. Dermatol, 86(3): 507-515.

Smits WTM., 1996. Arenga pinnata, (Wurmb) Merrill, in Plants Resources of SouthEast Asia. No. 9. Plants yielding nonseed carbohydrates, Editor: Flach, M. and Rumawas, F., Prosea Foundation, Bogor, Indonesia: 237.

Subchan P., Malik DA., Nahason WT., 2011. Fotoproteksi. MDVI, 38(3).

Suwartapradja OS., 2003. Arenga pinnata: A Case Study of Indigenous Knowledge on the Utilization of A Wild Food Plant in West Java, [online at: http://arenindonesia.wordpress.com /makalah-aren/opan-s-suwartapradja/]

Smijs TG., and Pavel S., 2011), Titanium dioxide and zinc oxide nanoparticles in sunscreens: focus on their safety and effectiveness, Nanotechnology, Science and Applications, 4: 95-112

Wakefield G., Lipscomb S., Hollanda E., and Knowland J., 2004. The effects of manganese doping on UVA absorption and free radical generation of micronised titanium dioxide and its consequences for the photostability of UVA absorbing organic sunscreen components, Photochem. Photobiol. Sci., 3: 648-652

Whenny, Rusli R., Rijai L., 2015. Aktivitas Tabir Surya Ekstrak Daun Cempedak
(Artocarpus champeden spreng), Jurnal Sains dan Kesehatan. 1(4)

Yasin RA., 2017. Uji Potensi Tabir Surya Ekstrak Kulit Buah Jeruk Nipis (Citrus aurantifolia) Secara In Vitro, [Skripsi], Fakultas Kedokteran dan Ilmu Kesehatan, Universitas Islam Negeri Alauddin, Makassar 